рення, але й саморефлексувати, налаштувати психофізичний стан, зібрати внутрішню волю, контролювати себе, бути мотивованим, розуміти виконуваний матеріал, 3 його семантичними та герменевтичними рефлексіями. Лише баланс цих факторів буде підгрунтям для втілення творчого акту у виконуваному творі.

\title{
Література:
}

1. Вознюк О.В. Розвиток вітчизняної педагогічної думки: синергетичний підхід. Житомир, вид-во ЖДУ ім. І. Франка. 2009. 150 с.

2. Гребенюк Н. Є. Вокально-виконавська творчість: психологопедагогічний та мистецтвознавчий аспекти: монографія. Вінниця: НМАУ ім. П. І. Чайковського, 1999. 212 с.

3. Кушка Я. Методика навчання співу: посібник з основ вокальної майстерності. Тернопіль: Навчальна книга «Богдан», 2010. 316 с.

4. Мирончук Н.М. Змістові характеристики самоорганізації праці викладача вищого навчального закладу // Формування дидактичної компетентності педагогів дошкільної та початкової освіти: зб. наук.метод. праць / за ред. В.С. Литньова, Н.Є. Колесник, Т.В.Наумчук. Житомир: Вид-во ЖДУ ім. І. Франка, 2015. - С. 64-68.

5. Свідзинсьий А. Синергетична концепція культури. Луцьк: Вежа, 2008. $696 \mathrm{c.}$

DOI https://doi.org/10.30525/978-9934-26-173-2-43

\section{ОСОБЛИВОСТІ РОБОТИ ВИКЛАДАЧА АНГЛІЙСЬКОЇ МОВИ У ВИЩИХ НАВЧАЛЬНИХ ЗАКЛАДАХ УКРАЇНИ В УМОВАХ ДИСТАНЦЙНОГО НАВЧАННЯ}

\author{
Ніколаєва Т. М. \\ кандидат філологічних наук, \\ доцент кафедри іноземної філології \\ Київський національний університет культури і мистецтв \\ м. Київ, Україна
}

Останнім часом у зв'язку з переходом ЗВО на дистанційне навчання виникла гостра необхідність у створенні та використанні інноваційних засобів в галузі освіти i, зокрема, у викладанні іноземних мов. Аналіз сучасних трендів у вищій освіті, тобто тенденцій в іiі зміні, вказує на визнання дистанційного навчання одним 3 пріоритетних напрямків. 160 
Однак слід зазначити, що навчання другої іноземної мови за допомогою комп'ютерних технологій постійно зазнає змін у зв'язку 3 технологічними інноваціями, які кидають виклик усталеним традиційним уявленням про те, як викладання та навчання іноземним мовам має здійснюватися за допомогою викладача і без нього.

Загальні цілі навчання іноземних мов також зазнали змін. В системі Загальноєвропейських компетенцій володіння іноземною мовою підкреслюється важливість «полілінгвізму і полікультурної компетентності» і міститься заклик до викладачів, щоб вони розвивали здатність своїх учнів застосовувати свої лінгвістичні та комунікативні компетенції в різних мовних і комунікативних ситуаціях. У світлі цих нових завдань багато викладачів іноземних мов звернули увагу на потенціал мережевих технологій для розширення та доповнення традиційної форми навчання комунікативному спілкуванню. Зокрема популярності нині набуває додаток Zoom, який є сервісом для проведення відео-конференцій та онлайн-зустрічей Разом з тим, викладачі англійської мови як іноземної в процесі використання сучасних інформаційно-комунікаційних технологій зіштовхуються з деякими психологічними бар'єрами та особливостями. Така ситуація диктує необхідність вивчення психологічних особливостей роботи викладача англійської мови у вищих навчальних закладах України в умовах дистанційного навчання.

Основний принцип навчання за умов дистанційної освіти - це пряма взаємодія студента 3 викладачем за допомогою інтернету. Принцип дистанційного навчання орієнтований, в першу чергу, на проведення інтерактивних занять у формі відеоконференції. Таке використання технологій (відеоматеріали, презентації, електронні словники, відеоконференції та ін.) Вже стає звичайною формою навчання. На сьогоднішній день технологічною основою впровадження дистанційного навчання $є$ освітні платформи, які дають можливість вчитися в зручний час в зручному місці. Під час навчанні іноземної мови дистанційно вельми ефективно вирішується більшість дидактичних завдань. При цьому змінюється роль викладача, у якого основне завдання стимулювати розвиток особистості учня, направляти його творчий пошук. Відносини зі студентами будуються на принципах співпраці. Природно, що необхідна трансформація організаційних форм навчальної роботи, а саме: упор на самостійну роботи і збільшення кількості робіт дослідницького характеру. Особливо, якщо мова йде про бакалаврів і спеціалістів старших курсів або магістрантів.

Використання систем дистанційної освіти у ВНЗ змінює роль викладача англійської мови як другої іноземної, точніше роль викладача 
стає більш важливою, а його функції розширюються. Це можливо за умови усвідомлення самими викладачами цієї ролі і функцій.

Зараз вже всі розуміють, що дистанційне навчання має колосальні інформаційні можливості. Однак якими б властивостями не володів той чи інший засіб навчання, роль викладача дуже важлива. Інтернет з усіма своїми можливостями і ресурсами - це тільки засіб реалізації цілей і завдань викладача іноземної мови. Відповідно роль викладача іноземної мови при дистанційному навчанні змінюється. Вони стають консультантами і кураторами навчальних груп. При цьому від них потрібні більш глибокі знання i вміння 3 організації роботи в телекомунікаційному середовищі в рамках поставлених дидактичних завдань:

- знання призначення, особливостей будови і функціонування комунікаційного середовища;

- знання умов зберігання і передачі інформації всередині мережі;

- знання основних мережевих інформаційних ресурсів i особливостей роботи з ними;

- знання особливостей організації та проведення телекомунікаційних проектів;

- знання особливостей організації та проведення тематичних телеконференцій;

- знання методичних основ організації роботи викладача і студентів в мережі;

- знання основних правил поведінки користувачів в мережі, основ телекомунікаційного етикету;

- вміння працювати 3 електронною поштою, телекомунікаціями, мережевими інформаційними службами;

- вміння відбирати і обробляти інформацію, отриману по мережі;

- вміння проводити пошук інформації по мережі;

- вміння готувати інформацію до передачі по мережі 3 використанням текстового редактора, графічного редактора і необхідних утиліт;

- вміння організувати, розробити і провести мережевий навчальний проект, тематичну телеконференцію.

Однак ефективність навчання можна підвищити тільки за рахунок викладання за допомогою інформаційних технологій. Ефективність дистанційного навчання залежить від організації процесу, від методичної якості матеріалів, які застосовуються на занятті, i, безумовно, від того, чи $\epsilon$ викладач, який бере участь в процесі навчання, майстром своєї справи, від його вміння мотивувати студентів на отримання ними знань, умінь і навичок, а також на формування 
необхідних компетенцій XXI століття, які будуть максимально затребувані в найближчому майбутньому.

\section{Література:}

1. Адамова I. 3., Уграк М. І. Використання інтернет-технологій у навчальному процесі. Вісник Чернівецького торговельно-економічного інституту. Економічні науки. 2014. Вип. 1. С. 374-379.

2. Андреев А. А., Солдаткин В. И. Дистанционное обучение и дистанционные образовательные технологии. Электронный журнал «Cloud of Science». 2013. № 1. С. 14-20.

3. Атрощенко, И.Г. Мобильные приложения и их использование в учебном процессе. Вестник Тверского государственного университета. Сер.: Педагогика и психология. 2019. № 2. С. 160-166.

4. Гуревич Р., Кадемія М. Навчання в мережі за допомогою електронних навчальних курсів. Проф.-техн. освіта. 2007. № 4. С. 24-27.

5. Дущенко О. С., Мізюк В. А. Інтернет у навчальному процесі. IHTЕРНЕТОСВITА-НАУКА-2014 : матеріали IX Міжнародної науковопрактичної конференції. (Вінниця, ВНТУ, 14-17 жовтня 2014 р.) Вінниця, 2014. С. 181-183.

6. Зарівна О. Т. Переваги та недоліки доцільності використання дистанційного навчання англійської мови. Наукові записки Національного університету «Острозька академія». Серія: Філологія.Острог : Вид-во НаУОА, 2016. Вип. 63. С. 82-85.

7. Калимуллина О. В. Современные цифровые образовательные инструменты и цифровая компетентость: анализ существующих проблем и тенденций. Открытое образование. 2018. № 3. С. 61-73.

8. Киянка В., Шаповал Т. Ресурси мережі інтернет як складова дистанційного навчання. Вісник Львівської національної академії мистецтв. Львів : Вид-во ЛНАМ, 2013. Вип. 24. С. 103-110.

9. Олійник О. В. Інноваційні технології дистанційного навчання іноземної мови для студентів немовних ВНЗ. Лінгвістичні дослідження. 2014. Вип. 38. С. 238-246. 